\title{
KONSTRUKSI GENDER MELALUI REPRESENTASI ALAM DALAM PUISI POST SCRIPTUM KARYA TOETY HERATY DAN THE SNAKE CHARMER KARYA SAROJINI NAIDU
}

\author{
Nimas Diah Putri Ayu Dewi Nastiti \\ Universitas Airlangga \\ e-mail: nimasdiah@gmail.com \\ Syaiful Qadar Basri \\ Universitas Negeri Surabaya \\ e-mail: jpoenkbadhoet@gmail.com
}

\begin{abstract}
Women are often considered to have close connection to nature. It can be seen form term Ibu Pertiwi. In Bahasa Indonesia, Ibu means mother and Pertiwi means earth. The term shows how women often be related to nature. Women's connection to nature can be seen as an advantage and a stereotype. This study discusses two poems; Post Scriptum by Toety Heraty and The Snake Charmer by Sarojini Naidu. This study aims to see how women being related to nature through the representation of nature to answer the connection whether as an advantage or as a stereotype. This study finds that women's connection to nature in Post Scriptum should not be celebrated. The connection shows the operation of social norms power (Cultural Ecofeminism). However, in The Snake Charmer, women-nature connection is seen as symbol of women's pureness and greatness (Essentialism Ecofeminism). This study pay attention to the context of culture as the background of each poem being written by the writer.
\end{abstract}

Keywords: ecofeminism, gender

\begin{abstract}
ABSTRAK
Perempuan dianggap memiliki hubungan spesial dengan alam. Hubungan spesial tersebut dapat dilihat dalam kata "Ibu Pertiwi". Kata "Pertiwi" memiliki arti "Bumi" dan disandingkan dengan kata "Ibu" sebagai sebuah ungkapan yang menunjukkan perempuan sering dikaitkan dengan alam. Kedekatan tersebut dapat dianggap sebagai sebuah anugerah sekaligus bentuk stereotip. Tulisan ini menganalisis dua puisi Post Scriptum karya Toety Heraty dan The Snake Charmer karya Sarojini Naidu. Melalui dua karya tersebut, penelitian ini melihat cara perempuan direpresentasi melalui simbolisasi alam sehingga dapat menjawab apakah kedekatan perempuan dan alam merupakan konstruksi sosial ataukah bentuk yang sebenarnya. Tulisan ini menemukan bahwa hubungan perempuan dan alam dalam puisi Post Scriptum merupakan hal yang tidak patut untuk dirayakan. Pengaitan alam dan perempuan menunjukkan adanya operasi kuasa niliai-nilai sosial (Cultural Ecofeminism). Puisi The Snake Charmer ditemukan bahwa hubungan alam dan perempuan merupakan hal istimewa yang menunjukkan keagungan dan kesucian perempuan (Essentialism
\end{abstract}


Ecofeminism). Dalam konteks ini, analisis kedua puisi dikaitkan dengan konteks budaya yang melatarbelakangi penulisan karya.

Kata kunci: ecofeminisme, gender

\section{PENDAHULUAN}

Perempuan dianggap memiliki hubungan spesial dengan alam. Hal ini dijelaskan oleh Ruther dalam Warren bahwa gerakan perempuan dan gerakan lingkungan sesungguhnya saling berkaitan (Warren, 2000: xiii). Hubungan spesial tersebut dapat dilihat dalam kata "Ibu Pertiwi". Kata "Pertiwi" memiliki arti "Bumi" dan disandingkan dengan kata "Ibu" sebagai sebuah ungkapan yang menunjukkan bumi sebagai tempat hidup segala makhluk hidup. Kata tersebut dapat dilihat bahwa perempuan dianggap memiliki kedekatan yang lebih dengan alam. Contoh lain dapat dilihat dalam gerakan Chipko atau Chipko movement di India. Gerakan tersebut dilakukan oleh perempuan India untuk menolak penebangan hutan. Dari gerakan tersebut, perempuan digambarkan memiliki kepedulian yang lebih terhadap alam. Namun, apakah kedekatan perempuan dan alam merupakan sebuah anugerah ataukah justru sebuah beban?.

Contoh tersebut menjelaskan bahwa perempuan digambarkan dekat dan peduli dengan alam. Hal ini digambarkan pula bahwa perempuan merupakan bagian dari alam. Perempuan merupakan makhluk yang dianggap mampu memberikan harmonisasi pada alam. Akan tetapi, hubungan antara perempuan dengan alam tidak selalu terlihat baik. Hal ini dapat dilihat dari julukan yang ditujukan kepada perempuan seperti bitch, chick, catty, dan masih banyak lagi. Joan Dunayer dalam Encyclopedia of Women menjelaskan bahwa perempuan sering diberikan julukan dengan jenis-jenis hewan yang bukan merupakan predator sedangkan laki-laki sebaliknya. Hal tersebut menunjukkan bahwa ada sikap inferioritas terhadap perempuan melalui julukan yang terkait dengan nama-nama hewan terhadap mereka (Kramarae dan Spender, 2004:62). Kutipan 
tersebut menjelaskan bahwa julukan merendahkan yang diberikan kepada perempuan (menggunakan nama-nama hewan) merupakan bentuk diskriminasi berupa inferioritas. Contoh itu menjelaskan bahwa hubungan perempuan dengan alam tidak hanya dianggap sebagai sebuah anugerah atau kelebihan, melainkan hal itu dapat merupakan salah satu bentuk diskriminasi.

Berbeda dengan perempuan, laki-laki dianggap memiliki kedekatan dengan budaya daripada alam. Laki-laki dan budaya saling dikaitkan karena posisi dan perannya terhadap alam. Laki-laki oleh masyarakat patriarki digambarkan sebagai makhluk yang derajatnya lebih tinggi dari perempuan. Situasi yang sama juga terjadi terhadap budaya yang dianggap lebih tinggi dan bertugas mengadabkan. Budaya memiliki kemampuan sekaligus peran untuk mengubah bentuk alam dan menjadikannya menjadi pemenuh kebutuhan atau tujuan-tujuan lainnya (Rosaldo, Lamphere and Bamberger, 1974:72). Oleh karena itu, penjelasan tersebut dapat dipahami bahwa posisi budaya lebih tinggi dari alam karena kemampuannya merubah atau dengan kata lain, mengeksploitasi alam. Kondisi tersebut disebabkan karena adanya androsentris (male-centered thinking) yang menganggap bahwa laki-laki lebih superior.

Kedekatan laki-laki dengan budaya dan perempuan dengan alam menunjukkan adanya dualisme yang memposisikan mereka secara hirarki. Gender merupakan hasil konstruksi masyarakat. Laki-laki diposisikan lebih tinggi dari perempuan. Hal tersebut dapat dilihat dari adanya dualisme dalam mendefinisikan mereka seperti maskulin/feminin, rasional/irasional, kuat/lemah, dan lainnya. Dualisme terhadap gender tidak berdasarkan perbedaan biologis antara laki-laki dan perempuan. Chodorow mengatakan bahwa kesetaraan gender dapat terwujud apabila baik bayi laki-laki maupun perempuan diperlakukan dengan sama oleh orangtuanya (Agassi, 1986:167). Oleh karena itu, hal ini dapat dikatakan bahwa konstruksi sosial merupakan penyebab terjadinya ketidaksetaraan.

Jika peran dan dualisme pada gender merupakan hasil konstruksi, kedekatan antara perempuan dengan alam dan laki-laki dengan budaya juga 
merupakan konstruksi. Untuk mengetahuinya, tulisan ini menjawabnya dengan melakukan analisis terhadap dua puisi Post Scriptum karya Toety Heraty dan The Snake Charmer karya Sarojini Naidu. Melalui dua karya tersebut, tulisan ini membandingkan bagaimana perempuan yang dikaitkan dengan alam melalui representasi alam sehingga dapat menjawab apakah kedekatan perempuan dan alam merupakan konstruksi sosial.

Toety Heraty adalah seorang penulis perempuan di Indonesia yang dijuluki sebagai "satu-satunya wanita diantara penyair kontemporer terkemuka Indonesia". Dengan kata lain, Toety Heraty memiliki posisi dalam khasanah sastra Indonesia. Perempuan kelahiran 27 November 1973 ini telah melahirkan banyak karya, diantaranya adalah Sajak-sajak 33 pada tahun 1973, Seserpih Pinang Sepucuk Sirih tahun 1979, Mimpi dan Pretensi tahun 1982, hingga Antologi Puisi Indonesia yang berjudul Transendensi pada tahun 1995. Karyanya yang berupa antologi puisi berjudul Transendesi memiliki kekhasan tersendiri berupa sajaknya yang pendek namun berhasil berdiri sendiri dalam menghasilkan makna. Antologi puisi tersebut, satu puisi berjudul Post Scriptum, menggunakan diksi-diksi yang berhubungan dengan alam untuk mengekspresikan kritik terhadap konstruksi gender di Indonesia. Puisi berjudul Post Scriptum menjadi menarik untuk diteliti dalam kajian ini. Tulisan ini ingin melihat cara penggambaran perempuan melalui representasi alam dalam puisi tersebut.

Puis kedua yang akan dibandingkan dengan Post Scriptum adalah karya Saroji Naidu yang berjudul The Snake Charmer. Sama seperti Toety Heraty, Saroji Naidu adalah seorang penulis puisi perempuan dari India. Selain seorang penulis puisi, dia merupakan seorang aktivis dalam kemerdekaan India. Selain itu, dia juga merupakan gurbernur perempuan pertama di Provinsi Agra dan Oudh sejak 1947 hingga 1949. Dalam perjalanannya sebagai seorang penulis puisi, dia telah melahirkan tiga karya berupa kumpulan puisi berjudul Golden Threshold, The Bird of Time, dan The Broken Wings. Buku yang dia terbitkan 
terdapat satu karya yang berjudul The Snake Charmer. Karya itu menceritakan tentang sebuah bentuk tradisi yang mempertontonkan ular menari yang biasanya diiringi dengan lantunan musik dari seruling. Masyarkat India memiliki beberapa hewan yang disucikan, seperti sapi dan ular. Oleh karena itu, melalui penelitian ini, tulisan ini membandingkan posisi gender melalui representasi alam dalam kedua puisi.

Dalam menganalisis makna puisi, tulisan ini ini menggunakan teori ekofeminisme sebagai pisau analisis terhadap isu keterkaitan perempuan dan alam. Teori ini dianggap sebagai teori yang tepat karena teori ini membahas mengenai posisi laki-laki dan perempuan dalam hirarki gender melalui hubungannya dengan alam. Penggambaran alam seperti hewan dapat pula menunjukkan posisi gender. Dalam teori eko-feminism terdapat dua cabang yaitu cultural ecofeminism dan social ecofeminism. Cultural ecofeminism menjelaskan bahwa kedekatan antara perempuan dan alam merupakan sebuah anugerah atau hal positif terhadap kualitas kewanitaan (Plumwood, 2003:8). Social ecofeminism mengatakan bahwa kedekatan perempuan dan alam merupakan hasil konstruksi dan bukan merupakaan hal yang positif (Plumwood, 2003:10).

Studi ini bertujuan untuk mencari makna puisi Post Scriptum karya Toety Heraty dan The Snake Charmer karya Sarojini Naidu. Tujuan ini selanjutnya adalah untuk mencari tahu cara hubungan antara perempuan dan alam digambarkan dalam Post Scriptum karya Toety Heraty dan The Snake Charmer karya Sarojini Naidu.

\section{Teori dan Metode Penelitian}

Penelitian ini menggunakan teori ecofeminism. Val Plumwood menjelaskan bahwa ecological Feminism atau ecofeminism sesungguhnya merupakan respon terhadap dua masalah sosial yaitu feminisme dan gerakan lingkungan. Keduanya memiliki kesamaan satu sama lain (Plumwood, 2003:10). Kutipan tersebut dapat dipahami bahwa permasalahan yang dialami 
oleh perempuan dan alam memiliki kesamaan. Oleh karena itu, perempuan sering dihubungkan dengan alam. Hal tersebut sesuai dengan perjalanan sejarahnya. Ecofeminism berasal dari gerakan politik untuk melindungi lingkungan yang dilakukan oleh perempuan. Istilah ecofeminism akhirnya terbentuk pada tahun 1970 oleh Francoise d' Eaubonne. Ecofeminism memiliki dua cabang yaitu cultural atau essential ecofeminism dan social atau constructivist ecofeminism. Dua cabang tersebut saling bertentangan dalam melihat hubungan antara permpuan dengan alam.

Cultural atau essentialism ecofeminism merupakan respon terhadap adanya dualisme dalam mendefinisikan laki-laki dan perempuan seperti kuat/lemah, superior/inferior, rasional/emosional. Dualisme tersebut menempatkan posisi perempuan berada di bawah laki-laki. Cultural ecofeminism ingin merubah hirarki tersebut melalui hubungan perempuan dengan alam. Contohnya dalam sebuah istilah angel in the house yang bermakna perempuan sebagai makhluk yang mencukupi serta melindungi seluruh anggota keluarga. Peran-peran perempuan yang memberikan perlindungan dan pemenuhan kebutuhan kepada keluarga dianggap mampu menyeimbangkan alam, seperti yang diungkapkan oleh Plumwood bahwa "... women are able to harmonize the nature or in other words replaces the term 'angle in the house' to 'angle in the ecosystem' (Feminism and the Mastery of Nature 9). Ia melanjutkan pendapatnya bahwa posisi perempuan sebagai angle in the ecosystem merupakan versi sederhana dari adanya afirmasi terhadap kualitas feminin perempuan (Feminism and the Mastery of Nature 10). Oleh karena itu, cultural ecofeminism percaya bahwa hanya perempuan saja yang dapat memahami alam harus diposisikan lebih tinggi dari laki-laki.

Selain itu, cultural ecofeminism berpendapat bahwa hubungan antara perempuan dikarenakan aspek biologi. Sebagai contohnya adalah perempuan dapat mengandung dan melahirkan makhluk hidup. Hal ini dijelaskan oleh Plumwood yang mengatakan bahwa “women's emphaty, nurturance, 
cooperativeness, dan connectedness to nature are grounded in women's reproductive capacity" (Feminism and the Mastery of Nature 9). Oleh karena itu, cultural ecofeminism percaya bahwa hanya perempuan yang dapat membawa keharmonisan kepada dan dengan alam. Anggapan tersebut bertolak belakang dengan social ecofeminism.

Berbeda dengan cultural ecofeminism, social ecofeminism berpendapat bahwa hubungan antara perempuan dan alam tidaklah esensial melainkan hasil konstruksi sosial. Menurutnya, hubungan antara perempuan dengan alam merupakan salah satu bentuk diskriminasi terhadap perempuan. Hal ini didukung oleh pernyataan Plumwood sendii. Dia mengatakan bahwa hubungan antara perempuan dan alam tidak dapat dikatakan sebagai sebuah pujian atau keunggulan (Feminism and the Mastery of Nature 14). Pernyataan tersebut dapat menjelaskan bahwa ide mengenai kedekatan perempuan dan alam mensyaratkan inferiorisasi perempuan sebagai ibu bumi yang memiliki ciri-ciri pasif, makhluk reproduktif, tidak logis, dan lainnya. Ide mengenai hubungan perempuan-alam sesungguhnya berasal dari peran sosial perempuan di masyarakat. Seperti yang diketahui, perempuan termarginalkan ke dalam area privat seperti menjadi seorang ibu rumah tangga, perawat, sekretaris, dan lainnya. Peran perempuan dalam lingkungan privat menjadikan mereka memiliki tugas untuk melayani kebutuhan keluarga seperti menyediakan makanan. Oleh karena itu, peran perempuan dalam lingkup privat membuat mereka lebih dekat dengan alam demi memenuhi kebutuhan keluarganya.

Selain itu, social ecofeminism menjelaskan bahwa tidak hanya perempuan yang memiliki kemampuan untuk mengharmonisasikan alam. Laki-laki juga dapat memiliki kemampuan tersebut. Hal ini didukung oleh pendapat Val Plumwood bahwa "Women do not necessarily treat other women as sisters or earth as a mother; women are capable of conflict, of domination and even, in the right circumtances, of violence (Feminism and the Mastery of Nature 9). Oleh karena itu, konsep cultural ecofeminism dalam cabang ini dipertanyakan. 
Penelitian ini menggunakan pendekatan kualitatif interpretatif. Langkah awal dalam melakukan penelitian ini adalah dengan memilih objek material yaitu puisi Post Scriptum karya Toety Heraty dan The Snake Charmer karya Sarojini Naidu. Puisi Post Scriptum dipilih karena hal ini menggambarkan konstruksi perempuan melalui representasi alam. Selain itu, puisi Post Scriptum karya Toety Heraty dipilih karena memiliki kekhasan. Bentuk ini berupa sajaknya yang singkat. Sealin itu, sajak ini mampu berdiri sendiri dalam melahirkan makna. Puisi The Snake Charmer dipilih karena puisi ini menceritakan tentang tradisi pertunjukkan ular menari masyarakat India Oleh karena itu, dengan menggunakan pendekatan sastra bandingan, tulisan ini akan melakukan pembandingan terhadap kedua puisi tersebut sehinga dapat mengetahui bagaimana posisi gender melalui representasi alam dalam kedua puisi.

Penelitian merupakan penelitian kualitatif (Sutopo, 2006). Objek kajiannya adalah kedua tersebut puisi. Data berupa gagasan sastra hijau atau eko-feminis yang terpresetasi dalam karya sastra. Data itu dapat berupa ekspresi atau ungkapan yang menyimbolkan representasi alam dan perempuan. Langkah pertama yang dilakukan adalah dengan mencari makna dari masing-masing puisi. Setelah makna pada masing-masing puisi ditemukan, tulisan ini selanjutnya menganalisis objek tersebut dengan menggunakan teknik interpretasi seperti yang dikemukan oleh ecofeminism. Hal ini bertujuan untuk menjawab pertanyaan pada rumusan masalah agar mengetahui hubungan perempuan dan alam merupakan esensial ataukah hasil konstruksi sosial.

\section{HASIL DAN PEMBAHASAN}

Makna Puisi Post Scriptum karya Toety Heraty dan The Snake Charmer karya Sarojini Naidu 
Puisi pertama yang dibahas adalah puisi karya Toety Heraty yang berjudul Post Scriptum. Puisi ini ditulis pada tahun 1995. Puisi ini merupakan salah satu puisi dalam karya Toety Heraty yang berujudul Notslagi=Transendensi. Puisi ini terdiri dari dua bait yang sajaknya singkat. Berikut adalah puisinya.

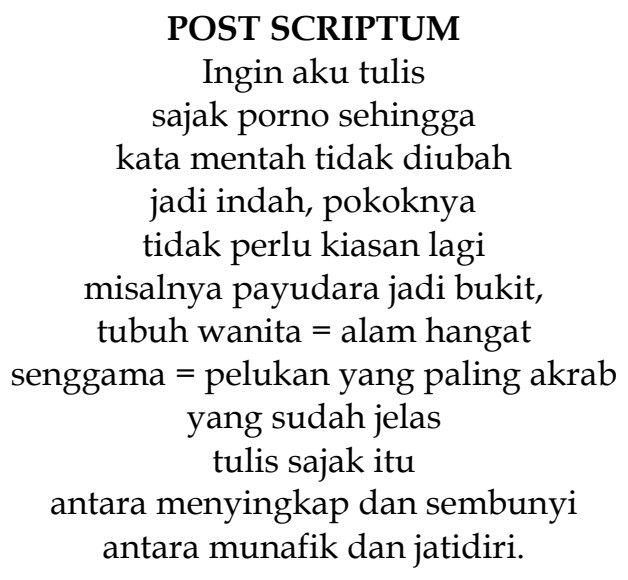

Puisi tersebut merupakan ekspresi penyair s yang mengkritik budaya tabu mengenai pembicaraan atau karya yang berbau seksualitas. Hal tersebut diakibatkan oleh masuknya budaya Barat yang dianggap beradab. Hal ini berhubungan dengan masa lalu atau zaman dahulu dari tradisi atau budaya mereka. Baginya, mereka memegang sebuah nilai yang berasal dari nilai-nilai Kristen ortodoks. Nilai-nilai itu mengatakan bahwa segala hal yang berkaitan dengan seksualitas yang berupa dosa. Oleh karena itu, hal itu tidak heran jika masyarkat Indonesia kemudian menganggap hal yang berkaitan dengan seksualitas merupakan hal yang tabu untuk dibicarakan. Fakta ini sekaligus menunjukkan bahwa karya dari penyair ini telah mengetengahkan isu-isu alam dan perempuan. Hal ini memberikan bukti bila puisi memberikan representasi tentang persoalan perempuan.

Nilai tersebut menggugah penyair puisi merespon melalui Post Scriptum. Dalam bait pertama, puisi itu berbunyi "Ingin aku tulis, sajak porno sehingga, kata mentah tak diubah, jadi indah, pokoknya, tidak perlu kiasan lagi". Lima baris dalam bait pertama tersebut menyatakan keinginan penyair untuk mendobrak anggapan tabu oleh masyakrat Indonesia terhadap tulisan-tulisan 
yang berbau seksualitas. Seksualitas menjadi simbol tentang kekuataan dan konstruksi anti perempuan. Hal ini semacam gagasan tentang usaha pembongkaran atas tubuh dan kuasa prerempuan. Fakta ini memberikan bukti bahwa puisi atau sastra dapat menjadi sarana atau tindakan sosial perempuan atas kuasa dan konsep alam dan kebudayaan. Baginya, kebudayaan meruakan logika yang menguasai alam atau perempuan seperti konsep modernitas (Russell, 2007). Salah satu contoh yang diberikan oleh penulis adalah kata-kata atau bunyi seperti berikut. kata-kata ini dapat bermakna oposisional atau oposisi biner. Sebagai contohnya adalah payudara beroposisi dengan jadi bukit, tubuh wanita dengan alam hangat, senggama dengan pelukan yang paling akrab. Kedua baris tersebut memberikan gambaran cara dalam mengalami pembatasan dalam mengekspresikan hal yang bersangkutan dengan seksualitas.

Baris ke lima pada puisi digambarkan bahwa untuk membahas payudara perempuan. Masyarakat lebih nyaman menggunakan istilah bukit. Jika hal itu dianalisis ucapan bukit sebagai penanda, $\mathrm{n}$ konsep bukit itu pada masing-masing individu adalah berbeda. Bukit, ketika diujarkan, dapat memunculkan penggambaran pegunungan. Konteks tertentu dapat memunculkan bagian tubuh wanita yaitu payudara. Penggunaan istilah bukti terhadap payudara secara tidak langsung menunjukkan sebuah situasi dalama mana masyarakat telah melakukan sebuah konstruksi.

Konsep nature dan culture menjadi bagian yang tidak bisa dipisahkan. Alam adalah perempuan dan kebudayaan adalah laki-laki. Alam dikuasai oleh kebudayaan seperti dalam cerita tentang penguasaan atau kontrol atas alam (Mirsa, 2016). Hal ini merupakan bagian dari upaya penolakan dan tindakan penyair untuk menolak konsep tersebut. fakta ini sekaligus menunjukkan bahwa konstruksi kultural atas keadaan tersebut ditentang dan dipertanyakan. Hal inilah yang menjadi kritik dari puisi tersebut. 
Fakta-fakta tersebut terus ulang seperti pada bait-bait selanjutnya. Perempuan memiliki kedekatan dengan alam. Situasi ini juga terulang pada baris selanjutnya, yaitu "tubuh wanita berasosiasi alam hangat". Lagi-lagi, perempuan diasosiasikan dengan alam. Analisis tersebut dapat disimpulkan bahwa makna puisi Post Scriptum ialah ekspresi atau keinginan untuk mendobrak nilai yang ada di masyarakat. Hal itu berhubungan dengan anggapan bahwa hal yang berkaitan dengan seksualitas adalah tabu dan tidak layak untuk diperbincangkan. Namun dalam penulisannya, penyair, Toety Heraty, memberikan contoh berupa penggunaan kata pengganti yang mengacu pada seksualitas dengan alam. Hal ini secara tidak langsung menunjukkan bahwa perempuan merupakan hal yang harus ditutupi.

Pada puisi tersebut, tulisan ini i menemukan adanya operasi kuasa atas aspek ekspresi seksualitas dalam karya sastra. Perempuan tidak dapat diekspresikan secara eksplisit. Hal ini seringkali ditutupi, didiamkan, dan diperhaluskan. Simbolisasi yang demikian menjadi karakteristik karya-karya perempuan pada masa itu. Hal tersebut menunjukkan bahwa ada kuasa nilai kesopanan yang mengatur masyarakat termasuk penyair dalam mengekspresikan karyanya. Fakta ini juga dikuatkan oleh konstruksi masyarakat terhadap hal itu. Dalam karya tersebut, penyair menunjukkan bentuk perlawanan terhadap nilai-nilai yang secara tidak sadar maupun sadar beroperasi sebangai bentuk kuasa terhadap masyarakat. Puisi selanjutnya yang dibahas berjudul The Snake Charmerkarya Sarojini Naidu. Berikut adalah puisinya.

\section{The Snake Charmer}

WHITHER dost thou hide from the magic of my flute-call? In what moonlight-tangled meshes of perfume, Where the clustering keovas guard the squirrel's slumber, Where the deep woods glimmer with the jasmine's bloom?

I'll feed thee, O beloved, on milk and wild red honey, I'll bear thee in a basket of rushes, green and white, To a palace-bower where golden-vested maidens Thread with mellow laughter the petals of delight. Whither dost thou loiter, by what murmuring hollows, 
Where oleanders scatter their ambrosial fire?

Come, thou subtle bride of my mellifluous wooing,

Come, thou silver-breasted moonbeam of de- sire!

Puisi itu berbeda dengan puisi sebelumnya. Puisi ini panjang dan memiliki tiga bait. Selain itu, tema dari puisi ini juga berbeda. Puisi ini menceritakan tentang sebuah tradisi yang ada pada masyarakat India. Tradisi ini merupakan sebuah ritual pemujaan ular. Dalam masyarakat India, ular merupakan salah satu hewan yang disucikan. Dalam tradisi tersebut, ular-ular dipuja dengan cara mendoakan mereka dan juga menawarkan mereka susu .Dalam puisi itu, puisi itu memperlihatkan bahwa ular dijelaskan sebabagi makhluk yang penuh dengan keindahan. Misalnya, hal itu ditunjukkan pada baris berikut "Come, thou subtle bride of my mellifluous wooing". Baris tersebut dapat diartikan bahwa "Kemarilah engkau pengantin yang diperebutkan milikku". Kata "thou" dalam sajak tersebut merujuk pada ular. Ular diibaratkan sebagai seorang pengantin perempuan yang diperebutan. Sajak tersebut dapat memperlihatkan bahwa dalam puisi tersebut ular digambarkan memiliki karakter seperti perempuan.

Keindahan ular selanjutnya juga tergambarkan pada sajak "Come, thou silver-breasted moonbeam of de-sire!". Jika dalam bahasa Indonesia, puisi tersebut dapat diartikan dengan "Kemarilah, engkau cahaya perak bulan bagai payudara penuh hasrat". Terjemahan sajak tersebut dapat dilihat bahwa sang ular diibaratkan memiliki keindahan bagaikan payudara wanita yang penuh hasrat dan juga bercahaya bagai bulan. Dalam sajak tersebut, ular memiliki karakter yang mirip dengan perempuan yaitu memiliki payudara. Selain itu, perempuan juga diibaratkan sebagai bulan. Bulan merupakan bagian dari alam. Oleh karena itu, hal ini dapat dikatakan bahwa dalam puisi berjudul The Snake Charmer. Perempuan digambarkan memiliki kedekatan dengan alam sebagai sebuah anugerah sesuai dengan konsep cultural ecofeminism (Glotfelty, dan Froomm, 1996). 
Penggambaran alam pada puisi tersebut menunjukkan adanya ecocentric. Hal ini pada dasar memiliki perspektif terhadap alam yang memposisikan alam sama dengan manusia. Hal ini diketahui melalui pengibaratan ular sebagai makhluk dengan ciri perempuan yang suci dan agung. Hal tersebut berbeda dengan puisi Post Scriptum. Tulisan ini melihat bahwa di dalamnya terdapat anthropocentric,. Perspektif ini memposisikan manusia sebagai pusat seperti pada karya-karya identitas kolonial (Faruk, 2007). Dalam puisi tersebut, alam tidak diposisikan sebagai yang utama, melainkan adalah manusia, yaitu perempuan. Perempuan berada pada pusat dalam mana dia tidak bisa diibaratkan dengan alam. Menurut puisi tersebut, penggambaran perempuan seharusnya tidak ditutup-tutupi dengan alam, melainkan hal itu dapat disampaikan atau diekspresikan dengan eksplisit.

\section{Konstruksi Gender melalui Representasi Alam dalam Puisi}

Analisis makna pada kedua puisi menemukan bahwa pada Post Scriptum karya Toety Heraty memandang bila tubuh perempuan sebagai hal yang harus ditutup. Selain itu, hal ini berhubungan dengan konstruksi masyarakat yang infin digugat bahwa simbolisasi alam dapat menyamarkan gagasan itu. hal ini sekaligus menunjukkan bahwa alam menjadi bagian dari perempuan. Dalam puisi tersebut, tubuh wanita berhubungan erat dengan alam. Hal yang sama juga terjadi pada puisi The Snake Charmerkarya Saroji Naidu. Puisi tersebut memposisikan perempuan sebagai makhluk yang memiliki sifat seperti alam. Namun, hal ini dapat dilihat dari perbedaan di antara keduanya. Hal ini berupa kedudukan perempuan yang diindahkan dalam puisi The Snake Charmer. Hal ini berkaitan dengan konstruksi gender yang ada di India. Masyarakat India memandang bahwa ibu merupakan manusia yang dijunjung tinggi. Bahkan, ibu menjadi kepala keluarga yang mengatur segala urusan sekaligus melindungi keluarganya.

Hal ini dapat dilihat bahwa puisi tersebut memiliki sudut pandang ecocentris dalam melihat alam. Alam dilihat sebagai sebuah anugrah dan wajib 
dijaga. Sudut pandang tersebut juga menjelaskan bagaimana posisi perempuan dalam masyarakat India, yaitu sebagai manusia yang memilki kuasa. Puisi ini berhubungan antara alam dan perempuan dilihat sebagai sebuah anugerah. Ggaasan ini merupakan gagasan cultural ecofeminism yang memandang hubungan antara alam dan perempuan merupakan kelebihan yang wajib dirayakan.

Hal tersebut berbeda dengan puisi Post Scriptum. Dalam puisi ini, perempuan lebih condong digambarkan sebagai manusia yang harus diajaga atau ditutupi karena tubuhnya. Hal tersebut dapat dimaknai bahwa perempuan adalah lemah dan tidak bisa menjaga dirinya. Oleh karena itu, fakta ini harus mengalami sensor. Puisi Post Scriptum menunjukkan bahwa perempuan juga diidentikkan dengan alam. Namun, posisi perempuan tidak ditunjukkan lebih kuat dari laki-laki. Situasi ini di latar belakangi ideologi patriarki di Indonesia yang mendefinisikan perempuan dan laki-laki dengan oposisi biner. Hal ini menempatkan laki-laki lebih tinggi (Wiyatmi, 2003). Oleh karena itu, fakta ini dapat disimpulkan bahwa hubungan perempuan dan alam dalam puisi Post Scriptum tidak dilihat sebagai hal yang perlu dirayakan. Sebba, hal ini merupakan salah satu bentuk diskriminasi terhadap perempuan. Atau dengen kata lain, puisi ini setuju dengan konsep constructivist ecofeminism yang menganggap hubungan perempuan dan alam adalah konstruksi sosial dan sebagai bentuk pelemahan terhadap perempuan.

\section{SIMPULAN}

Tulisan ini menyimpulkan bahwa perempuan dan alam dalam puisi Post Scriptum dan The Snake Charmer saling berhubungan dengan konsep nature and culture. Namun, dalam puisi The Snake Charmer, hubungan antara perempuan dan alam dilihat sebagai hal yang patut untuk dirayakan. Hal tersebut dikarenakan sifat-sifat perempuan yang digambarkan dengan penuh keindahan. Namun berbeda dengan puisi The Snake Charmer, puisi Post Scriptum 
dengan ideologi patriarki menggambarkan hubungan antara alam dan perempuan sebagai konstruksi sosial. Hal ini tidak patut untuk dirayakan karena hal ini dapat menjadi sebuah diskriminasi terhadap perempuan. Oleh karena itu, puisi Post Scriptum dapat dikatakan sebagai bentuk perlawanan terhadap nilai masyarakat yang mengkonstruksi seksualitas sebagai hal yang harus ditutupi atau didiamkan. Puisi The Snake Charmer memiliki kedekatan dengan perempuan dan alam. Hal ini dijelaskan sebagai anugerah yang menunjukkan keindahan perempuan.

Berdasarkan analisis, tulisan ini menemukan bahwa dalam puisi Post Scriptum menempatkan posisi perempuan yang dihubungkan dengan alam merupakan salah satu bentuk kuasa terhadap seksualitas. Aspek seksualitas tidak luput dari praktik kuasa sehingga seksualitas tidak dapat dibicarakan di sembarang forum. Namun, seksualitas didiamkan dan hanya dapat dinikmati dalam lembaga pernikahan. Situasi kuasa tersebut dapat dilihat melalui puisipuisi yang sering kali menggunakan alam untuk memperhalus atau menyamarkan penggambaran tubuh wanita maupun seksualitas. Oleh karena itu, melalui puisi tersebut, Toety Herati berusaha melawan kuasa dengan mengungkap batasan-batasan dalam penyebutan bagian tubuh wanita, sehingga dapat diungkapkan dengan eksplisit. Dengan kata lain, puisi Post Scriptum melihat hubungan antara perempuan dengan alam sebagai bentuk kontruksi masyarakat yang merugikan kaum perempuan.

Pada puisi The Snake Charmer, tulisan ini menemukan bahwa hubungan perempuan dengan alam diagungkan. Hal tersebut dipengaruhi oleh kebudayaan India yang mayoritas masyarakatnya memeluk agama Hindu. Hewan seperti sapi, ular, dan monyet dianggap memiliki hubungan dengan dewa yang mereka puja. Oleh karena itu, hal ini menghubungkan perempuan dengan hewan-hewan suci. Fakta ini menenjukkan bahwa dalam puisi tersebut menempatkan perempuan tidak lebih rendah dari laki-laki. Perempuan diposisikan sebagai makhluk yang suci dan indah. The Snake Charmer 
menganggap hubungan antara perempuan dengan alam sebagai keistimewaan atau dalam konsep teori ecofeminisme disebut dengan cultural ecofeminism.

\section{REFERENSI}

Agassi, J.B. (1986). "Theories of Gender Equality." Gender and Society (1989), hlm. 160-186.

Campbell, A.K. (2010). “Narrating Other Natures: A Third Wace Ecocritical Approach to Toni Morison, Ruth Ozeki, and Octavia Butler." Disertasi, Universitas Washington, tidak diterbitkan

Faruk, 2007. Belenggu Pasca Kolonial, Hegemoni \& Resistensi dalam Sastra Indonesia. Yogyakarta: Pustaka Pelajar

Francoine, GL. (1999) Humans are not Superior to Animals. America: Greenhaven Press,

George, J.C. (1978). Julie of the Wolves. New York: Scholastic Inc

George, J. C. (1988). My Side of the Mountain. New York: Scholastic Inc

Glotfelty, C.heryll \& Froomm, H. (1996). The Ecocriticism Reader: Landmark in Literary Ecology. Athens and London: The University of Georgia Press

Hornby, T. , et.all. (2010),. Oxford Advanced Learner's Dictionary, 8th Edition. Oxford: OUP Oxford

Kortenkamp, K. and Moore, C.. (2001). "Ecocentrism and Anthropocentrism: Moral Reasoning about Ecologiccal Commons Dilemmas." Journal of Environmental Psycology (2001), hlm. 1-11.

Kramarae, C. and Spender, Dale. (2004). Routledge International Encyclopedia of Women: Global Women's Issue and Knowledge. New York:

RoutledgePlumwood, V. (2003). Feminism and the Mastery of Nature.

Canada: Routledge

Mirsa, S.K. (2016). "Ecocriticism: A Study of Environmental Issues in Literature" BRICS Journal of Educational Research, Vol. 6, Issue 4, OctoberDecember 2016

Rosaldo, M.Z., , Lamphere, L., and Bamberger, J.. (1974). Women, Culture, and Society. Stanford: Stanford University Press

Russell, B. (2007). Sejarah Filsafat Barat; kaitannya dengan kondisi sosio politik zaman kuno hingga sekarang (penerjemah: Sigit Djatmiko dkk). Yogyakarta: Pustaka Pelajar

Sutopo, H.B. 2006. Metodologi Penelitian Kualitatif: Dasar Teori dan Terapannya dalam Penelitian. Surakarta: Universitas Sebelas Maret.

Warren, K. J. (2000). Ecofeminist Philosophy: A Western Perspective on What It Is and Why It Matters. Maryland: Rowman \& Littlefield Publisher

Wiyatmi. 2003. "Feminisme dan Dekonstruksi terhadap Ideologi Familialisme dalam Novel Saman Karya Ayu Utami” Diksi. Vol. 10. No. 2, Juli 2003. 